\title{
PROFESINIS STRESAS IR JO POVEIKIS MOKYTOJŲ SVEIKATAI: KIEKYBINĖS APKLAUSOS DUOMENYS
}

\author{
Daiva Bubeliené $\dot{1}^{1}$, Gediminas Merkys ${ }^{2}$ \\ ${ }^{1}$ Kauno kolegijos Medicinos fakultetas, ${ }^{2}$ Kauno technologijos universiteto \\ Socialiniu, humanitariniu mokslu ir menu fakultetas
}

Raktažodžiai: profesinis stresas, pedagogai, sveikata, klinikiniai simptomai

\begin{abstract}
Santrauka
Straipsnis skirtas atskleisti sąryšius tarp pedagogu profesinio streso ir dirbančiu pedagogų sveikatos būklès. Studijos teorinè koncepcija remiasi darbine hipoteze, kad pedagogo profesija pasižymi padidèjusiu stresu, dideliu psichiniu krūviu ir tai ilgainiui neigiamai paveikia dirbančių pedagogų sveikatos būklę. Pristatomi Lietuvos pedagogų ( $\mathrm{N}=961)$ kiekybinès apklausos duomenys. Profesiniam stresui matuoti panaudoti 25 pirminiai kintamieji, atspindintys ịvairius darbinius stresorius. Iš pirminių kintamujų sudarytos 8 poskalès ir jungtinè skalè, pasižyminčios tinkama psichometrine kokybe. Pedagogų sveikatos būklei vertinti taikyta subjektyvaus savijautos įsivertinimo skalè, susidedanti iš 19-kos klinikinių simptomų ir pasižyminti tinkama psichometrine kokybe. Maždaug kas trečias mokytojas $(32,65$ proc.) kenčia nuo padidejusio profesinio streso ir maždaug kas ketvirtam mokytojui $(29,03$ proc.) sistemingai pasireiškia konkretūs klinikiniai simptomai. Tarp jungtiniu „profesinio streso“ ir „klinikinių simptomų“ skalių egzistuoja vidutinio stiprumo labai patikimas koreliacinis ryšys $(r=0,50$; $\mathrm{p}=0,000$ ). Naudojant diskriminacinę analizę buvo ieškoma, kurie klinikiniai simptomai leidžia visų geriausiai atskirti (diskriminuoti) pedagogų grupes, pasižyminčias sąlygiškai aukštu ir žemu stresuotumu. Paaiškejjo, kad dvi kontrastinès grupès skiriasi pagal visus 19-ka klinikinių simptomų. Visų geriausiai minètas kontrastines pedagogų grupes skiria psichinę sveikatą ir psichini išsekimą atspindintys simptomai.
\end{abstract}

\section{Ivadas}

Šiuo metu visuotinai pripažinta, kad nuolatinis stresas yra daugelio sveikatos sutrikimų priežastis. Stresas anaiptol yra ne vienintelé, galbūt ne visada pati stipriausia, bet pakankamai reikšminga daugelio ligų priežastis. Neigiamas streso poveikis sveikatai yra irodytas daugelyje didelès apimties ir patikimų empirinių studijų [22, 26, 30, 32]. PSO prognozuoja, kad dèl neigiamo streso poveikio netrukus pati grèsmingiausia žmonijai ligų rūšis bus psichikos ligos, nors šiandien kaip didžiausios ir labiausiai išplitę grèsmès iš inercijos vis dar figūruoja onkologinès ir širdies bei kraujagyslių ligos [11]. Beje stresas turi įtakos toms pačioms širdies ir kraujagyslių bei onkologinèms ligoms.

Modernizacija greta privalumų turi ir savo kainą, viena iš jų yra nuolatinis ir vis stiprejantis stresas, kuris totaliai ịsitvirtina visose šiuolaikinio žmogaus gyvenimo būdo struktūrose. Gyvenimo ir darbo tempas, šiuolaikinès medijos, skaitmeninès technologijos, vartojimo stimulų, galimybių ir gyvenimo scenarijų ịvairové, vis didèjantis ateities neapibrěžtumas, konkurencijos ir pasiekimų kultas, modernybę ištinkanti gyvenimo prasmès krizė [5]. Visa tai verčia keisti požiūrị ị stresą ir skatina intensyviai ieškoti streso ir jo pasekmiu ịveikos priemonių, beje, ne vien medicininių. Trivialus paaiškinimas, kad stresas tai - individualaus atsako ị didejantị psichofizinị krūvị deficitas, šiandien yra akivaizdžiai per siauras. Tarkime, individo apsišvitinimas arba apsinuodijimas negali būti laikomi grynai endogeninès kilmès klinikinèmis pasekmèmis ta prasme, kad jos kyla ne iš organizmo vidinès saviraidos, bet iš jo sąveikos su aplinka. Taip ir streso sukeltos klinikinès pasekmès yra laikytinos sąveikos tarp individo ir makrosocialinès aplinkos rezultatu.

Atskira tema yra profesinis stresas ir jo pasekmès sveikatai. Stresas smogia individui ir visuomenei, nelyginant klastinga seismine banga, net kelis kartus. Ilgalaikis stresas sukelia profesinį perdegimą, sugriauna darbinę motyvaciją. 
Tada drastiškai krenta darbo našumas ir paslaugų kokybė, dèl ko, savo ruožtu, kyla didžiulè ekonominè žala. Galiausiai ilgalaikis stresas darbe sukelia ligas, ịskaitant profesines, apriboja individo galimybes ir gyvenimo kokybę, tampa našta bei iššūkiu visai sveikatos ir socialinès apsaugos sistemoms [2, 12, 16, 17, 19, 22, 26].

Modernybès sąlygomis tokio reiškinio, kaip rami darbo vieta, stabili organizacija, tiesiog nebelieka, bet kuris dirbantis individas nuolat susiduria su tokiu iššūkiu, kaip nuolatinis stresas. Visgi egzistuoja profesijos, kurių atstovai dešimtmečiais nuolatos yra priversti dirbti padidejusio streso sąlygomis. Šiame kontekste pirmiausia paminètinos profesijos yra: mokytojas, slaugytojas ir medikas, gaisrininkas, kariškis, policininkas, autobuso vairuotojas ir pan. $[1,3,8,9,14,17,28]$.

Platesnis požiūris ị profesinį stresą, jo socioekonominę ir sociokultūrinę determinaciją skatina supratimą, jog veiksminga streso ịveika yra sietina tik su kompleksinemis priemonèmis. Klinikinès medicininès, edukacinès priemonès turi būti derinamos su politinemis ir organizacinès kultūros kaitos priemonèmis. Turima galvoje atitinkama sveikatos ir socialinè politika, ekonominè ir užimtumo politika, taip pat sveikatą tausojančios, socialiai atsakingos organizacijos modelio ịtvirtinimas, galiausiai visos visuomenès persiorientavimas į „laimès ekonomiką“, atsisakant ligšiolinès ekonomikos, orientuotos vien tik ị konkurenciją, pelną ir nuolat augantị vartojimą, besąlygiško dominavimo [25].

Profesinio streso poveikis mokytojų sveikatai, profesinių ligų genezei yra neblogai ištyrinètas $[1,10,13-15$, $18,21,23,24,27,30-33]$. Visgi kol kas stinga duomenų, konkrečių populiacinių tyrimų, kurie nušviestų Lietuvos pedagogų bendruomenès situaciją šiuo klausimu. Lietuvos situacija ịdomi tuo, kad ji reprezentuoja specifini ES šalių klasterį, kurị sudaro ekonomiškai silpnos buvusios sovietinès bei vadinamojo socialistinio bloko šalys. Pedagogo profesija šiose šalyse pasižymi savitu „socialiniu profiliu“ - žemas, socialiai neteisingas atlyginimų ir pensijų lygis, (nors dauguma darbuotojų turi universitetinį išsilavinimą), beviltiškai smukęs mokytojo profesijos prestižas, profesijos feminizacija, profesijos senèjimas ir pan. Visa tai susiję su bendra švietimo sektoriaus ir jo profesinès bendruomenès marginalizacija. Deklaracijų lygyje visuomenè, mokytojai nuolat apdalinami pažadais apie būsimą gražų proveržį, švietimo sektoriaus prioritetiškumą, tačiau realybejje niekas nesikeičia dešimtmečiais.

Lietuvos visuomeneje, teisèkūroje vyksta diskursas dèl konkrečių socialinès ir sveikatos politikos priemonių, kurios būtų nukreiptos ị profesinès pedagogų bendruomenès gerovès ir sveikatingumo užtikrinimą. Pagrịstai siūloma didinti profesijos prestižą ir atlygị, išsaugoti ilgesnes atostogas, tobulinti mokytojų darbo krūvio apskaitą bei normavimą, sudaryti galimybę pedagogams anksčiau išeiti i pensiją [29]. Deja, šie išmintingi ir nevèluojantys ketinimai bei politikos priemonès mūsų šalyje inertiškai lieka neịgyvendintos ir pagrindiné priežastis čia yra ekonominiai motyvai ir finansinių išteklių stygius.

Tyrimo tikslas - ištirti statistinius sąryšius tarp pedagogų profesinio streso ir nusiskundimu ịvairiais klinikiniais simptomais. Šiame straipsnyje pristatomi masinès pedagogų apklausos duomenys [6, 7, 20,21], kurie leidžia atidžiau pažvelgti ị profesinio streso paplitimo mastą bei jo netiesioginị poveikị atitinkamos profesinès grupès sveikatai. Gauti duomenys aktualizuoja būtinybę mokytojų profesinès bendruomenès atžvilgiu aktyviau diegti konkrečias užimtumo, socialinès ir sveikatos politikos priemones.

\section{Tyrimo objektas ir metodika}

Apklausos imtis. Tyrimo duomenų bazè sudaryta apklausus raštu 961 mokytoją. Apklaustieji dèsté įvairius dalykus ir atstovavo įvairiems mokyklų tipams - pradinei, pagrindinei ir vidurinei mokykloms, gimnazijoms. Geografiniu požiūriu imtyje reprezentuojami bemaž visi Lietuvos administraciniai teritoriniai regionai, kaimo ir miesto specifika atspindèta. Respondentų amžius - nuo 23 iki 70 metų (vidurkis 43,7 o standartinis nuokrypis - 10,2 m.). Imtis labai asimetriška pagal lytį, mokytojų vyrų imtyje yra tik 9,3 proc., tačiau tai atitinka faktines demografines mokyklų pedagoginio personalo realijas, žinomas iš centralizuotos žinybinès statistikos. Turint galvoje imties tūrị, imties lizdų ịvairovę ir jų geografinị išsibarstymą, galima teigti, kad suformuota imtis visumoje atstovauja tikslinei populiacijai - dirbantiems Lietuvos mokytojams. Šio apklausos tyrimo imties paklaida, paskaičiuota maksimalios sklaidos meto$\mathrm{du}$, sudaro 3,1 proc., kai $\alpha=0,05$.

Pirminiai apklausos indikatoriai ir skalès. Pedagogų profesiniam stresui matuoti buvo naudojami 25 pirminiai apklausos indikatoriai. Klausimas skambejo: „Žemiau išvardinti įvairūs streso šaltiniai (stresoriai). Ties kiekvienu stresoriumi pažymèkite, kiek, jūsų nuomone, jums jis yra stiprus ar nestiprus". Taikytas tradicinis 5 pakopų Likert'o tipo atsakymu registravimo formatas, kur 1 balas ,nekelia streso“, 5 balai - „ labai stiprus“. Derinant loginę ir faktorinę validaciją buvo sudarytos 8 poskalès, pasižyminčios nebloga psichometrine kokybe (1 lentelè). Viena iš poskalių sudaryta iš vienintelio kintamojo: indikatorius apie pertrauką, kaip streso šaltinį, pasirode svarbus turinio požiūriu, tad jo nesinorejo iš analizès proceso išmesti. Neprastą sudarytų poskalių, matuojančiu profesinị stresą, kokybę liudija aukšti faktoriniai svoriai, didelis paaiškintos sklaidos (PS) nuošimtis faktoriniame modelyje ir aukštos 
1 lentelè. Pedagogų profesinio streso pirminiai indikatoriai, poskalių psichometriniai rodikliai ir sąryšis su subjektyvaus sveikatos įsivertinimo (klinikinių simptomų) skale; $\mathrm{N} \approx 961$

Pastaba: PS - faktorinio modelio paaiškinta sklaida; SB - Spearmen 'o-Brown koeficiento prognozuojama reikšmé, kai testo ilgis 10 žingsniu; R- Pearson'o koreliacijos koeficientas tarp profesinio streso poskalès ir klinikiniu simptomu skalès; *** $p=0,000$.

\begin{tabular}{|c|c|c|c|c|c|c|}
\hline $\begin{array}{l}\text { Vidutinis } \\
\text { TAIP \% }\end{array}$ & $\begin{array}{l}\text { POSKALĖS PAVADINI- } \\
\text { MAS }\end{array}$ & $\begin{array}{c}\text { PIRMINIAI APKLAUSOS INDIKA- } \\
\text { TORIAI }\end{array}$ & $\begin{array}{l}\text { Labai } \\
\text { sti- } \\
\text { prus } \\
\text { stresas } \\
(\%) \\
\end{array}$ & $\begin{array}{l}\text { Faktori- } \\
\text { nis svo- } \\
\text { ris } L \\
\text { poska- } \\
\text { lèje } \\
\end{array}$ & SB & $\mathbf{R}$ \\
\hline \multirow[t]{2}{*}{$48,4 \%$} & \multirow{2}{*}{$\begin{array}{l}\text { PROBLEMIŠKI IR AGRE- } \\
\text { SYVŪS TĖVAI } \\
\text { PS }=79,7 \%\end{array}$} & $\begin{array}{l}\text { Santykiai su klasės tèvais, kurie visiškai } \\
\text { nesidomi savo vaikais ir mokykla }\end{array}$ & 38,8 & 0,89 & \multirow[t]{2}{*}{0,97} & \multirow[t]{2}{*}{$0,36 * * *$} \\
\hline & & $\begin{array}{l}\text { Santykiai su konfliktiškai ir agresyviai } \\
\text { nusiteikusiais tèvais }\end{array}$ & 58,0 & 0,89 & & \\
\hline \multirow[t]{3}{*}{$44,0 \%$} & \multirow{3}{*}{$\begin{array}{l}\text { ŽEMAS ATLYGIS, VISUO- } \\
\text { MENĖS SPAUDIMAS, } \\
\text { IVAIZDIS } \\
\text { PS }=65,0 \%\end{array}$} & $\begin{array}{l}\text { Žiniasklaidoje „piešiamas“ } \\
\text { arba sukarikatūrintas pedagogo ịvaizdis }\end{array}$ & 51,6 & 0,84 & \multirow[t]{3}{*}{0,95} & \multirow[t]{3}{*}{$0,38 * * *$} \\
\hline & & Visuomenès spaudimas & 29,9 & 0,83 & & \\
\hline & & Nepakankamas atlyginimas už darbą & 50,5 & 0,74 & & \\
\hline \multirow[t]{2}{*}{$41,7 \%$} & \multirow{2}{*}{$\begin{array}{l}\text { DEMOTYVUOTI MOKI- } \\
\text { NIAI, VAIKAI IŠ PROBLE- } \\
\text { MINIU ŠEIMŲ } \\
\text { PS=75,9\% }\end{array}$} & $\begin{array}{l}\text { Santykiai su nemoksliais, neturinčiais } \\
\text { mokymosi motyvacijos vaikais }\end{array}$ & 49,4 & 0,87 & \multirow[t]{2}{*}{0,96} & \multirow[t]{2}{*}{$0,36^{* * *}$} \\
\hline & & $\begin{array}{l}\text { Santykiai su vaikais iš socialiai proble- } \\
\text { miniu šeimy }\end{array}$ & 34,0 & 0,87 & & \\
\hline $36,4 \%$ & $\begin{array}{l}\text { TRIUKŠMINGA PERTRAU- } \\
\text { KA (kvazi-poskale iš vieno } \\
\text { indikatoriaus) }\end{array}$ & Triukšminga pertrauka mokykloje & 36,4 & $\begin{array}{ll}--- \\
\end{array}$ & $\begin{array}{ll}--- \\
-1\end{array}$ & $0,38^{* * *}$ \\
\hline \multirow[t]{6}{*}{$33,53 \%$} & \multirow{6}{*}{$\begin{array}{l}\text { DARBO KRŪVIS, POKY- } \\
\text { ČIAI, PAMOKỤ STEBĖJI- } \\
\text { MAS } \\
\text { PS }=45,7 \%\end{array}$} & Pasiruošimas pamokoms & 16,6 & 0,70 & \multirow{6}{*}{0,97} & \multirow{6}{*}{$0,51 * * *$} \\
\hline & & Dokumentacijos tikrinimas & 36,1 & 0,69 & & \\
\hline & & Nuolatiniai pokyčiai & 38,6 & 0,69 & & \\
\hline & & $\begin{array}{l}\text { Didelis pedagoginio darbo krūvis (pamo- } \\
\text { kos, neformali veikla) }\end{array}$ & 32,1 & 0,73 & & \\
\hline & & Išorinis pamokų stebejjimas & 56,8 & 0,67 & & \\
\hline & & Darbo grafikas, tvarkaraštis & 21,0 & 0,56 & & \\
\hline \multirow[t]{2}{*}{$23,0 \%$} & \multirow{2}{*}{$\begin{array}{l}\text { SPEC. POREIKIUU VAIKAI: } \\
\text { GABUSS IR SILPNI } \\
\text { PS }=65,6 \%\end{array}$} & $\begin{array}{l}\text { Santykiai su integruotais ị klasę neiga- } \\
\text { liaisiais vaikais }\end{array}$ & 19,2 & 0,81 & \multirow[t]{2}{*}{0,90} & \multirow[t]{2}{*}{$0,31 * * *$} \\
\hline & & $\begin{array}{l}\text { Santykiai su stipriais mokiniais, kurie la- } \\
\text { bai pretenzingi, reikalauja demesio }\end{array}$ & 26,8 & 0,81 & & \\
\hline \multirow[t]{4}{*}{$21,23 \%$} & \multirow{4}{*}{$\begin{array}{l}\text { ORGANIZACIJOS SPAU- } \\
\text { DIMAS IR REIKALAVIMAI } \\
\text { MOKYTOJUI } \\
\text { PS }=52,7 \%\end{array}$} & $\begin{array}{l}\text { Reikalavimai dalyvauti projektinèje vei- } \\
\text { kloje }\end{array}$ & 24,8 & 0,74 & \multirow[t]{4}{*}{0,95} & \multirow{4}{*}{$0,41 * * *$} \\
\hline & & Klasès materialinis aprūpinimas & 23,8 & 0.67 & & \\
\hline & & Reikalavimai kelti kvalifikaciją & 19,9 & 0,77 & & \\
\hline & & $\begin{array}{l}\text { Reikalavimai naudotis naujomis moky- } \\
\text { mo technologijomis }\end{array}$ & 16,4 & 0,72 & & \\
\hline \multirow[t]{5}{*}{$12,92 \%$} & \multirow{5}{*}{$\begin{array}{l}\text { SANTYKIAI SU KOLEGO- } \\
\text { MIS, ADMINISTRACIJA, } \\
\text { TEVVU AKTYVU } \\
\text { PS }=52,9 \%\end{array}$} & Santykiai su mokyklos direktoriumi & 17,8 & 0,64 & \multirow{5}{*}{0,98} & \multirow{5}{*}{$0,37 * * *$} \\
\hline & & Santykiai su kolegomis & 6,4 & 0,68 & & \\
\hline & & Santykiai su klasės tėvų aktyvu & 12,0 & 0,74 & & \\
\hline & & Santykiai su specialistais & 8,7 & 0,78 & & \\
\hline & & Santykiai su pavaduotoju/pavaduotojais & 19,7 & 0,78 & & \\
\hline 32,65 & ------ & ----- & --- & --- & --- & $0,50 * * *$ \\
\hline
\end{tabular}

Spearmen`o Brown koeficiento reikšmès. Konkrečiai buvo taikoma prognozuojama minèto koeficiento reikšmè, jeigu pirminių indikatorių skalèje skaičius būtų 10. Iš aštuonių poskaliu įverčių buvo suformuota jungtinè pedagogų profesinio streso skalè, pasižyminti aukšta vidine konsistenci-

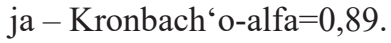


Toliau buvo naudojama situacinès savijautos subjektyvaus įsivertinimo skale, susidedanti iš 19-kos pirminių indikatorių (2 lentelè). Klausimo formuluoté buvo tokia: „Atejjus ị mokyklą, užsibuvus mokykloje dažnam mokytojui pablogejja savijauta. Ar jums pasireiškia šie simptomai - žr. simptomų lentelę“. Taikytas 4 pakopu atsakymo formatas: „visai nèra“, „labai retai“. „dažnokai“, „bemaž nuolat“. Turinio požiūriu indikatoriai gali būti traktuojami kaip klinikiniai simptomai, žinoma, tik subjektyvios ịsivertinimo teisèmis.

Išmetus iš požymių struktūros indikatorių „nukritęs kraujospūdis" buvo gauta psichometriné skalé, pasižyminti aukšta vidine konsistencija Kronbach'oalfa $=0,89$, Spearmen'o-Brown $=0,83$, koreliacija tarp dviejų testo dalių $-0,71$.

Aštuonios pedagogų streso poskalès bei abi jungtinès skalès (profesinio streso ir simptomų) buvo transformuotos i standartinio normaliojo skirstinio z-skalę. I analogišką z-skalę buvo transformuota ir 19-ka pirminių indikatorių, matuojančių subjektyvų savijautos įsivertinimą pagal konkrečius simptomus. Visų transformuotų skalių ir pirminių kintamụjų z-ịverčiai yra artimi teoriniam normaliajam skirstiniui.

Statistiniai metodai. Psichometrinèms skalèms sudaryti, kaip jau minèta, buvo naudojama faktorinè analizé, pagrindinių komponenčių metodas. Matuojamų požymių raiškai tikslinèje populiacijoje apibūdinti buvo naudojamas ir toks rodiklis, kaip pritarimo procentas ( TAIP\%). Jis gaunamas sudejus procentinius dažnius, tenkančios dviem paskutinèms Likert'o skalès kategorijoms. Galima išvesti vidutini pritarimo procentą, tenkanti atitinkamos poskalès teiginiams. Borg I. Gabler S. (2002) atliko metodologinę studiją ir parodè, kad pritarimo procentai yra aiškiau suvokiami, nei tradiciniai Likert'o skalès vidurkiai [4].

Buvo skaičiuojamos koreliacijos koeficiento (r) reikšmès. Konkrečiai buvo skaičiuojama, kaip kiekviena iš 8 profesinio streso poskalių koreliuoja su subjektyvaus savijautos ịsivertinimo pagal konkrečius simptomus skale.

Toliau jungtinès pedagogų profesinio streso skalès ivverčiai buvo transformuoti ị grupini kintamaji. Grupių sudarymui buvo panaudotas medianos metodas. Iverčiai žemiau medianos atspindi „žemo stresuotumo“ grupę, o ịverčiai aukščiau medianos atspindi ,aukšto stresuotumo" grupę. Tada buvo pasitelkta diskriminantinè analizè. Buvo ieškoma, kaip 19-ka pirminių simptomų atskiria (diskriminuoja) dvi pedagogų grupes „žemo stresuotumo“ ir „aukšto stresuotumo“.
2 lentelè. Diskriminantinès analizès rezultatai.

Žymèjimai: lyg. gr. lyginamos grupės (+ ,žemas stresuotumas“, - ,aukštas stresuotumas"); Taip\% - pritarimas simptomams lyginamose grupèse; vid.- grupių vidurkiai zskalèje; Skirt.-vidurkių skirtumų modulinè reikšmė; $\mathbf{p}$-patikimumas (vidurkių lygybès patikra Wilks' Lambda testu); SM koef. - struktūrinés matricos koeficientas

\begin{tabular}{|c|c|c|c|c|c|c|}
\hline \multicolumn{2}{|c|}{$\begin{array}{l}\text { Priklausomas kintamasis: „žemo } \\
\text { stresuotumo“ versus „aukšto stre- } \\
\text { suotumo“ grupé }\end{array}$} & \multirow[b]{2}{*}{$\begin{array}{c}\text { Taip } \\
\%\end{array}$} & \multicolumn{4}{|c|}{$\begin{array}{l}2 \text { kontrastinès pedagogu gru- } \\
\text { pès; df1 }=1, \text { df } 2=794\end{array}$} \\
\hline $\begin{array}{l}\text { Nepriklausimi kintamieji } \\
\text { Subjektyvus sveikatos } \\
\text { iqsivertinimas: klinikiniai } \\
\text { simptomai }\end{array}$ & $\begin{array}{l}\text { lyg. } \\
\text { gr. }\end{array}$ & & Vid. & Skirt. & $\mathbf{p}$ & $\begin{array}{c}\text { SM } \\
\text { koef. }\end{array}$ \\
\hline 1 & 2 & 3 & 4 & 5 & 6 & 7 \\
\hline \multirow[t]{2}{*}{ Padidejjęs dirglumas } & + & 28,2 & $-0,37$ & \multirow[t]{2}{*}{0,75} & \multirow[t]{2}{*}{0,000} & \multirow[t]{2}{*}{0,758} \\
\hline & - & 59,6 & 0,38 & & & \\
\hline \multirow{2}{*}{$\begin{array}{l}\text { Sunku susikaupti, išlaikyti } \\
\text { dèmesi }\end{array}$} & + & 11,6 & $-0,39$ & \multirow[t]{2}{*}{0,74} & \multirow[t]{2}{*}{0,000} & \multirow[t]{2}{*}{0,749} \\
\hline & - & 34,7 & 0,35 & & & \\
\hline \multirow[t]{2}{*}{ Staigus nuotaikų svyravimas } & + & 20,7 & $-0,34$ & \multirow[t]{2}{*}{0,70} & \multirow[t]{2}{*}{0,000} & \multirow[t]{2}{*}{0,709} \\
\hline & - & 47,3 & 0,36 & & & \\
\hline \multirow{2}{*}{$\begin{array}{l}\text { Slopinimas, mieguistumas, } \\
\text { apatija }\end{array}$} & + & 21,8 & $-0,35$ & \multirow[t]{2}{*}{0,68} & \multirow[t]{2}{*}{0,000} & \multirow[t]{2}{*}{0,685} \\
\hline & - & 49,6 & 0,33 & & & \\
\hline \multirow[t]{2}{*}{ Nerimo ir panikos priepuoliai } & + & 9,0 & $-0,34$ & \multirow[t]{2}{*}{0,66} & \multirow[t]{2}{*}{0,000} & \multirow[t]{2}{*}{0,657} \\
\hline & - & 27,0 & 0,32 & & & \\
\hline \multirow[t]{2}{*}{ Galvos skausmas } & + & 34,4 & $-0,31$ & 0,57 & 0,000 & 0,557 \\
\hline & - & 61,5 & 0,26 & & & \\
\hline Trūksta oro, dusimas & + & 8,3 & $-0,27$ & 0,54 & 0,000 & 0,530 \\
\hline & - & 23,0 & 0,27 & & & \\
\hline Padidintas prakaitavimas & + & 17,6 & $-0,26$ & 0,50 & 0,000 & 0,488 \\
\hline & - & 36,0 & 0,24 & & & \\
\hline Galvos svaigimas & + & 18,2 & $-0,28$ & 0,49 & 0,000 & 0,488 \\
\hline & - & 38,7 & 0,21 & & & \\
\hline Sutrinka virškinimas ir žarny- & + & 24,4 & $-0,28$ & 0,49 & 0,000 & 0,474 \\
\hline no veikla & - & 45,1 & 0,21 & & & \\
\hline ras valgyti, nèra & + & 8,5 & $-0,25$ & 0,46 & 0,000 & 0,452 \\
\hline & - & 19,7 & 0,21 & & & \\
\hline Nugaros skausmai & + & 33,4 & $-0,25$ & 0,42 & 0,000 & 0,404 \\
\hline & - & 54,2 & 0,17 & & & \\
\hline Skauda sąnarius, tirpsta & + & 21,5 & $-0,25$ & 0,39 & 0,000 & 0,385 \\
\hline galūnès & - & 36,7 & 0,14 & & & \\
\hline & + & 16,9 & $-0,21$ & 0,37 & 0,000 & 0,355 \\
\hline Skausmas širdies plote & - & 30,4 & 0,16 & & & \\
\hline Atsiranda padidintas noras & + & 23,4 & $-0,22$ & 0,37 & 0,000 & 0,351 \\
\hline & - & 35,6 & 0,15 & & & \\
\hline & + & 17,6 & $-0,20$ & 0,36 & 0,000 & 0,351 \\
\hline Širdies permušimai & - & 30,8 & 0,16 & & & \\
\hline & + & 19,5 & $-0,18$ & 0,34 & 0,000 & 0,333 \\
\hline Ėda rèmuo & - & 32,7 & 0,16 & & & \\
\hline & + & 19,1 & $-0,15$ & 0,28 & 0,000 & 0,267 \\
\hline Nukritęs kraujospūdis & - & 27,1 & 0,13 & & & \\
\hline & + & 26,5 & $-0,12$ & 0,18 & 0,010 & 0,175 \\
\hline Padidintas kraujospūdis & - & 32,8 & 0,06 & & & \\
\hline & + & 20,0 & $-0,26$ & & & \\
\hline Vidutinès reikšmès & - & 38,0 & 0,23 & 0,49 & --- & --- \\
\hline $\begin{array}{l}\text { Modelio charakteristikos } \\
\text { Savoji verte }=0,28 ; \text { kanoninès } \\
\text { Chi-square }=188,013 ; \mathrm{df}=19 ; 1 \\
\text { centroidai „žemo stresuotumo }\end{array}$ & then & 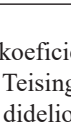 & $\operatorname{tas}=c$ & 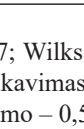 & $-70,0$ & $\begin{array}{l}=0,781 \text {; } \\
\text { Grupiu }\end{array}$ \\
\hline
\end{tabular}




\section{Tyrimo rezultatai}

Paaiškejjo, jog vidutiniškai bemaž kas trečias mokytojas (32,65 proc.) sistemingai patiria profesinị stresą. Jis yra sąlygotas įvairių profesinių veiksnių bei kontekstų. Tai rodo toks dydis kaip vidutinis pritarimo procentas, gautas ịvertinus 25 stresorius. İvairūs stresoriai pasižymi nevienodu paveikumu, tai liudija vidutiniai pritarimo procentai, tenkantys atskiroms stresorių grupems, kurios aiškiai rikiuojasi pagal reitingo dèsnị (1 lentelè).

Vidutiniškai daugiau nei kas ketvirtas mokytojas $(29,03$ proc.) jaučia ịvairius klinikinius simptomus. Šitoks vidutinis pritarimo procentas tenka 19-kai simptomų, kurie mokytojams buvo pateikti subjektyvaus situacinès savijautos įsivertinimo skalëje. Ypač verta dèmesio yra šio rodiklio variacija lyginamose pedagogų grupèse. Antai ,žemo stresuotumo" pedagogu grupeje vidutinis pritarimo procentas 19-kai klinikinių simptomų siekia tik 20,03 proc. Per 19-ką požymių šis rodiklis svyruoja nuo 8,3 proc. iki 34,4 proc. „Aukšto stresuotumo“ pedagogų grupejje analogiškas rodiklis jau šokteli bemaž dvigubai - iki 38,03 proc. ir atitinkamai svyruoja nuo 19,7 proc. iki 61,5 proc.

Kad pedagogų stresuotumo laipsnis sistemingai (ir beje neigiamai) paveikia pedagogų klinikinius simptomus (subjektyvaus įsivertinimo prasme), rodo ir koreliacinè analizè. Koreliacijos koeficientas (r) tarp profesinio streso skalès ịverčių ir klinikinių simptomų skalès ịverčių siekia 0,50 punktą ir yra labai patikimas $\mathrm{p}=0,000$. Kadangi streso poskalès koreliuoja tarpusavyje, taikyti daugiamatės tiesinès regresijos modeli atsisakyta. Tiesiog buvo paskaičiuoti koreliacijos koeficientai tarp 8 profesinio streso poskalių ir jungtinès klinikinių simptomų skalès (2 lentelè). Aštuonios koeficientų reikšmès svyruoja nuo 0,31 iki 0,51 ir visos tenkina labai griežtą statistinio patikimumo sąlygą $\mathrm{p}=0,000$.

Toliau prasminga išsiaiškinti, kurie konkretūs klinikiniai simptomai geriausiai atskiria (diskriminuoja) „žemo“ ir ,aukšto“ stresuotumo pedagogu grupes? Klausimą galima formuluoti ir kiek kitaip, pagal kokius konkrečius klinikinius savijautos simptomus lyginamos pedagogu grupès, pasižyminčios skirtingu stresuotumo laipsniu, skiriasi visu ryškiausiai? I šitokio pobūdžio klausimą geriausiai atsako diskriminantinès analizès rezultatai (2 lentelè).

Šios analizès rezultatai pakankamai iškalbingi. Lyginamos pedagogų grupès skiriasi pagal visus 19 simptomų. Visi skirtumai statistiškai labai patikimi. Vidutinis skirtumas tarp grupinių ìverčių siekia $0,49 \mathrm{z}$ - skalès punktus. Didžiausias pasitaikęs skirtumas siekia 0,75 z-skalès punktus ir sudaro $3 / 4$ standartinio nuokrypio. Mažiausias skirtumas tarp grupinių ịverčių siekia 0,18 ir sudaro bemaž $1 / 5$ standartinio nuokrypio. Pats iškalbingiausias lentelèje yra struktūrinès matricos koeficientas. Jis interpretuojamas panašiai, kaip ir faktorinis svoris. Kuo aukštesnè koeficiento reikšmè, tuo atitinkamas požymis geriau atskiria (diskriminuoja) lyginamas grupes. Yra akivaizdu, kad aukštu ir žemu stresuotumu pasižyminčias grupes visų geriausiai skiria su psichine sveikata ir/arba su psichiniu išsekimu susiję simptomai.

Iš populiacinès apklausos studijos, kurios imtis artima reprezentatyviai, aiškèja, kad pedagogų profesinis stresas sistemingai paveikia ịvairius klinikinius simptomus (subjektyvaus savijautos ịsivertinimo) prasme. Didesnis tirtos profesijos atstovų stresuotumas paprastai sukelia stipresnius klinikinius simptomus, nusiskundimus savijauta. Žinoma, interpretuojant duomenis, reikia turèti galvoje, kad visi sąryšiai, nustatyti tarp pedagogu profesinio streso ir savijautos darbe, remiasi tik subjektyviais ,klausimyninès kilmès" indikatoriais. Suprantama, kad ateityje visai prasminga būtų paieškoti sąryšių tarp pedagogų stresuotumo laipsnio ir objektyvesnès prigimties sveikatingumo indikatorių. Informacija apie juos galètų būti sugeneruota iš anamnezès, ligos istorijos, objektyvių klinikinių duomenų apie faktinę tiriamųjų sveikatos būklę.

Vertas démesio studijoje aptiktas statistinis désningumas, jog profesinis stresas neigiamai paveikia visus savijautos įsivertinimo (klinikinius) kintamuosius. Tai rodo, kad profesinis stresas yra realus ir sistemingai pedagogu savijautą bei sveikatą paveikiantis veiksnys. Indikatoriai, silpniausiai atskiriantys aukšto ir žemo stresuotumo pedagogų grupes, yra sietini su tokiais indikatoriais, kaip kraujospūdžio padidejimas ir/arba pamažejimas. Kaip žinoma iš medicinos teorijos ir klinikinès praktikos, kraujospūdis, ypač padidejjęs, yra rimtas klinikinis simptomas. Todèl aptikto radinio apie sąlygini šio veiksnio silpnumą nereikètų sureikšminti. Iš 19-kos simptomų visi yra nustatomi subjektyviai, išskyrus du rodiklius apie kraujospūdi, kurie, kaip žinia, nustatomi objektyviai, išmatuojant prietaisu. Taigi, aptiktas radinys gali būti apklausos metodo šalutinis efektas. Apskritai komentuojamo radinio kontekste galètume kelti klausimą, koks nuošimtis mokytojų savo darbo stalo stalčiuje laiko kraujo spaudimo matavimo prietaisą ir kaip reguliariai darbe tikrinasi savo spaudimą? Simptomiška, kad kraujospūdžio kintamujų prastesnị tinkamumą sudarytai visuminei apklausos požymių struktūrai, kaip jau minèta, parode ir psichometrinè analizè. Išmetus tuos du kintamuosius, skalès vidinè konsistencija pagerèja.

Apklausos studijos duomenys rodo, kad profesinis stresas komentuojamoje profesijoje pirmiausia kèsinasi i dirbančių pedagogų psichinę sveikatą, sukelia psichinį išsekimą. Aptiktas statistinis désningumas, mūsų nuomone, turi reikšmès sveikatos politikai ir konkrečioms jos priemonèms. Pedagogų profesijos padidejęs stresuotumas yra 
pripažintas visuotinai. Kaip minèta, šios profesijos atstovai turi pailgintas atostogas, savitą darbo apskaitos sistemą, kai kuriuose kraštuose yra anksčiau išleidžiami i pensiją. Klausimas dèl paankstinto pedagogų išleidimo i pensiją buvo svarstomas ir LR Seime, deja, atitinkami teisèkūros pasiūlymai buvo atmesti iš esmès dèl ekonominių motyvų. Šiuo metu, prièmus naują LR darbo kodeksą, vèl kyla rizika, kad i pedagoginio darbo specifiką nebebus atsižvelgiama visai. Atlikta apklausos studija patvirtina, kad pedagogo profesinè veikla yra susijusi su padidintu psichiniu krūviu, paženklinta stipriu profesiniu stresu, kuris nuolat ir sistemingai veikia dirbančio pedagogo sveikatą.

\section{Išvados}

1. Vidutiniškai bemaž kas trečias mokytojas $(32,65$ proc.) sistemingai patiria stiprų profesinį stresą. Vidutiniškai daugiau nei kas ketvirtas mokytojas (29,03 proc.) jaučia stipriai ir reguliariai išreiktus klinikinius simptomus.

2. Pedagogų profesinis stresas sistemingai paveikia ịvairius klinikinius simptomus (subjektyvaus savijautos isivertinimo) prasme. Kuo stipresnis profesinis stresas, tuo aštriau pasireiškia konkretūs klinikiniai simptomai.

3. Kaip stipriausi prediktoriai, visu geriausiai atskiriantys „,stresuotų“ ir „mažai stresuotu““ pedagogų kontrastines grupes, pasireiškia psichinę sveikatą atspindintys klinikiniai simptomai.

4. Pedagogų profesinei bendruomenei, tikètina, tikslinga taikyti konkrečias sveikatos ir socialinès politikos priemones: ankstesnị išleidimą ị pensiją, specifinị darbo krūvio normavimą ir ilgesnę atostogų trukmę ir kt.

\section{Literatūra}

1. Arvidsson I, Håkansson C, Karlson B, Björk J, Persson R. Burnout among Swedish school teachers - a cross-sectional analysis. BMC Public Health 2016; 16: 1-11. doi:10.1186/ s12889-016-3498-7

http://dx.doi.org/10.1186/s12889-016-3498-7

2. Bogaert I, De Martelaer K, Deforche B, Clarys P, Zinzen E. Associations between different types of physical activity and teachers' perceived mental, physical, and work-related health. BMC Public Health 2014;14(1): 1492-1511. doi:10.1186/14712458-14-534

http://dx.doi.org/10.1186/1471-2458-14-534

3. Bonnie M, Jennings D.N. Work stress and burnout among nurses: role of the work environment and working conditions. In Hughes RG (ed.) Patient safety and quality: An evidencebased handbook for nurses. 2008; Rockville, MD: Agency for Healthcare Research and Quality.

4. Borg I, Gabler S. Zustimmungsanteile und Mittelwerte von Liker-skalierten Items. ZUMA Nachrichten; 2002; 26, 50: 7-25. Prieiga per internetą: <http://nbn-resolving.de/ urn:nbn:de:0168-ssoar-207887>. [žiūrèta 2015 m. gruodžio 23 d.].

5. Boucekkine R, Hritonenko N, Yatsenko Y. Health, work intensity, and technological innovations. Journal of Biological Systems 2014; 22(2): 219-233.

http://dx.doi.org/10.1142/S0218339014400038

6. Bubelienė D, Merkys G. Bandymas žvelgti ị pedagogų profesini stresą kompleksiškai: empirinio tyrimo duomenys. Mokytojų ugdymas, 2010;14(1):88-102.

7. Bubeliené D. Mokytojų profesinis stresas ir jo redukavimo prielaidos švietimo vadybos bei edukacinėmis priemonemis. Daktaro disertacija. Socialiniai mokslai, edukologija (07S). Šiauliai. Šiaulių universitetas, 2010.

8. Chan A, Chen K, Chong E. Self-reported stress problems among teachers in Hong Kong. AIP Conference Proceedings 2010; 1285(1):420-434

http://dx.doi.org/10.1063/1.3510566

9. DeValk M, Oostrom Ch. Burnout in the medical profession: causes, consequences and solutions. Occupational Health at Work 2007; 4(1): 24-28

10. Fisher M. H. factors influencing stress, burnout, and retention of secondary teachers. Current Issues in Education 2011; 14(1). Prieiga per internetą: <http://cie.asu.edu/ > [žiūréta 2013-05-06].

11. Health impact of the psychosocial hazards of work: an overview. Prieiga per internetą: $<\mathrm{http}: / /$ www.who.int/occupational_health/publications/hazardpsychosocial/en/> [žiūrèta 2016-09-25].

12. Ingersoll R, Merrill $\mathrm{E}$. The status of teaching as a profession. In Ballantine, J., Spade, J. (Eds.) Schools and Society: A Sociological Approach to Education 2011; 185-189 4th Ed. CA: Pine Forge Press/Sage Publications. Prieiga per internetą: $<$ http:// repository.upenn.edu/gse_pubs/221> [žiūrèta 2013-05-06].

13. Kidger J, Brockman R, Tilling K. et. al. Teachers' wellbeing and depressive symptoms, and associated risk factors: A large cross sectional study in English secondary schools. Journal of Affective Disorders, 2016; 192: 76-82. doi:10.1016/j. jad.2015.11.054

http://dx.doi.org/10.1016/j.jad.2015.11.054

14. Klizas Š., Šulnienė R. Stresas pedagogų darbe priklausomai nuo ugdymo įstaigos. Sveikatos mokslai, 2012; 22(5): 5-8.

http://dx.doi.org/10.5200/sm-hs.2012.089

15. Klusmann U, Kunter M, Trautwein U, Lüdtke O, Baumert J. Engagement and emotional exhaustion in teachers: Does the school context make a difference? Applied Psychology: An International Review 2008; 57: 127-151. http://dx.doi.org/10.1111/j.1464-0597.2008.00358.x

16. Kovač M, Leskošek B, Hadžić V, Jurak G. Occupational health problems among Slovenian physical education teachers. Kinesiology 2013; 45(1): 92-100

17. Kovess-Masféty V. et al. Do teachers have more health problems? Results from a French cross-sectional survey. BMC Public Health 2006; 6:101. 
http://dx.doi.org/10.1186/1471-2458-6-101

18. López J.M.O, Bolavo C.C, Mari-o M.J.S. exploring stress, burnout, and job dissatisfaction in secondary school teachers. International Journal of Psychology and Psychological Therapy 2010; 10(1): 107-123

19. McCarthy C, Lambert R, Lineback S, Fitchett P, Baddouh P. assessing teacher appraisals and stress in the classroom: review of the classroom appraisal of resources and demands. Educational Psychology Review 2016; 28(3): 577-603. http://dx.doi.org/10.1007/s10648-015-9322-6

20. Merkys G., Bubelienè D. Profesinis stresas pedagogų akimis: grupinių interviu rezultatai. Mokslas ir edukaciniai procesai, 2009; 2 (9): 115-134.

21. Merkys G, Bubelienė D. Profesinio perdegimo įveika ir hobis: mokytojų apklausos duomenys. Acta Paedagogica Vilnensia, 2013; 13: 110-125.

http://dx.doi.org/10.15388/actpaed.2013.31.2511

22. Mielczarek A, Kasprzak J.D, Marcinkiewicz A, Kurpesa M, Uznańska-Loch B, Wierzbowska-Drabik K. Broken heart as work-related accident: occupational stress as a cause of takotsubo cardiomyopathy in 55-year-old female teacher - role of automated function imaging in diagnostic workflow. International Journal Of Occupational Medicine \& Environmental Health 2015; 28(6), 1031-1034. doi:10.13075/ijomeh.1896.00564 http://dx.doi.org/10.13075/ijomeh.1896.00564

23. Mouza A, Souchamvali D. Effect of greece's new reforms and unplanned organizational changes on the stress levels of primary school teachers. Social Indicators Research 2016; 128(2): 981-994. http://dx.doi.org/10.1007/s11205-015-1065-8

24. Narayanappa S, Manjunath R, Kulkarni P. metabolic syndrome among secondary school teachers: exploring the ignored dimension of school health programme. Journal Of Clinical \& Diagnostic Research 2016;10(4):10-14.

http://dx.doi.org/10.7860/jcdr/2016/14868.7631

25. Navaitis G. Geriausias pasirinkimas: laimingesnès Lietuvos galimybè. Vilnius: Versus aureus, 2012.

26. Paton N. Evolution of occupational health 4: Making health a work priority. Occupational Health 2015; 67(12): 11-13.

27. Pisanti R, Gagliardi M.P, Razzino S, Bertini M. Occupational stress and wellness among Italian secondary school teachers. Psychology \& Health 2003; 18(4), 523-536. http://dx.doi.org/10.1080/0887044031000147247

28. Selmanovic S, Ramic E, Pranjic N, Brekalo-Lazarevic S, Pasic Z, Alic A. Stress at work and burnout syndrome in hospital doctors. Medical Archives 2011; 65(4): 221-4. http://dx.doi.org/10.5455/medarh.2011.65.221-224

29. Strazdas V. Ankstyvesnè mokytojų pensija - kaip vaivorykštė. Dialogas, 2010; 40.

30. Von Känel R, Bellingrath S, Kudielka B.M. Overcommitment but not effort-reward imbalance relates to stress-induced coagulation changes in teachers. Annals Of Behavioral Medicine
2009; 37(1), 20-28.

http://dx.doi.org/10.1007/s12160-009-9082-y

31. Wei-Chih C. Leisure participation, job stress, and life satisfaction: moderation analysis of two models. Social Behavior \& Personality: An International Journal 2016;44(4): 579-588. http://dx.doi.org/10.2224/sbp.2016.44.4.579

32. Zurlo M, Pes D, Capasso R. Personality characteristics, job stressors, and job satisfaction: main and interaction effects on psychological and physical health conditions of Italian schoolteachers. Psychological Reports 2016;119(1): 27-38 http://dx.doi.org/10.1177/0033294116656818

33. Zurlo M.C., Pes D, Cooper C.L. Stress in teaching: a study of occupational stress and its determinants among Italian school teachers. Stress \& Health: Journal Of The International Society For The Investigation Of Stress 2007; 23(4), 231-241.

http://dx.doi.org/10.1002/smi.1141

\section{OCCUPATIONAL STRESS AND ITS IMPACT ON TEACHERS' HEALTH: SURVEY RESULTS D.Bubelienè, G.Merkys}

Key words: occupational stress, teachers, health, clinical symptoms.

Summary

The article is intended to reveal the relationship between teachers' occupational stress and health status of working teachers. Theoretical concept of the study is based on the hypothesis that the occupation of the teacher has the increased stress, high mental workload and it will eventually negatively affect health condition of working teachers. The study presents the quantitative survey data of Lithuanian teachers $(\mathrm{N}=961)$. In order to measure the occupational stress there are used 25 primary variables that reflect the different work stressors. The primary variables are used to create 8 subscales and a joint scale that are specified with appropriate psychometric quality. In order to evaluate health status of the teachers, there was applied the consisting of 19 clinical symptoms subjective well-being scale with the appropriate psychometric quality. Approximately every third teacher (32. 65\%) suffers from increased occupational stress and approximately every fourth teacher $(29.03 \%)$ systematically gets specific clinical symptoms. There is a very reliable positive correlation $(\mathrm{r}=0.50 ; \mathrm{p}=0.000)$ between joint "occupational stress" and "clinical symptoms" scales. Discriminant analysis was used to define the clinical symptoms that enable to separate (to discriminate) teachers' groups who possess relatively high and low level of stress. It turned out that two contrasting groups differ in all 19 clinical symptoms. The most evident are the symptoms reflecting the status of mental health and mental exhaustion.

Correspodence to: gediminas.merkys@ktu.lt

Gauta 2016-10-14 